\title{
Alternative Histories in Youssef Ziedan's Azazeel : Historiographic Metafiction in the Contemporary Arabic Historical Novel ${ }^{(*)}$
}

\author{
Dr. Hala Mohamed Kamel Amin \\ Assistant Professor - Department of English \\ Faculty of Al-Alsun - Beni Suef University
}

\begin{abstract}
Drawing on Linda Hutcheon's theory, this article reads Azazeel as a historiographic metafiction. It argues that the novel not only denounces the so-called religious, or religiously-motivated, violence but also has an additional epistemological import, articulated in the novel's historiographic metafictional narrative which, in accordance with Hutcheon's theory, provides an alternative history that foregrounds the 'narrativity' of historical narratives and represents the past from a 'marginal' perspective to question the absolute authority of metanarratives, undermine monolithic notions of knowledge, and develop a balanced production and dissemination of knowledge. The article examines the novel's use of historiographic metafictional techniques which reflect its thematic content and its espousal of the postmodern ideology of diversity and pluralism. The article demonstrates that, without denying its heritage, Azazeel engages with the global postmodern condition, locates the Arabic historical novel within the wider context of world historical fiction, and opens up new avenues for research on historiographic metafiction.
\end{abstract}

${ }^{(*)}$ Bulletin of the Faculty of Arts Volume 81 Issue 2 January 2021 
السرديات التاريخية البديلة في رواية "عزازيل" للكاتب يوسف زيدان: ما وراء القص التاريخي في الرواية التاربخية العربية المعاصرة د/ هالة محمد كامل أمين

مدرس- قسم اللغة الانجليزيةـ كلية الألسن- جامعة بنى سويف كالف مين

\section{الملخص : - (المص}

تقدم المقالة قراءة في ضوه نظريات ليندا هتشون لرواية عزازيل للكاتب يوسف

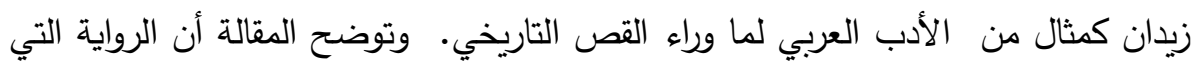
تدور أحداثها حول الأحداث الدامية في مصر و شمال سوريا في القرن الخامس الميلادي

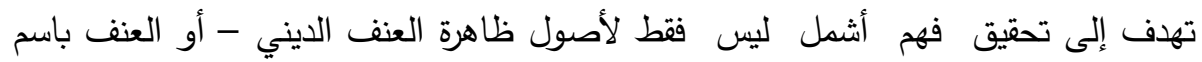

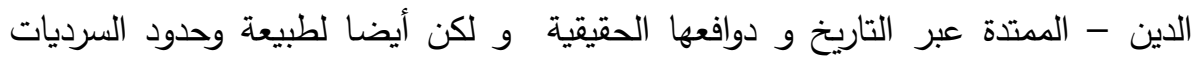

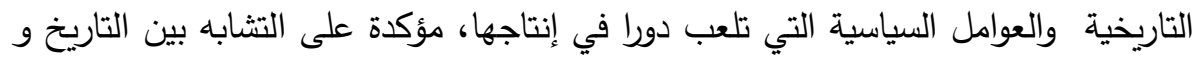

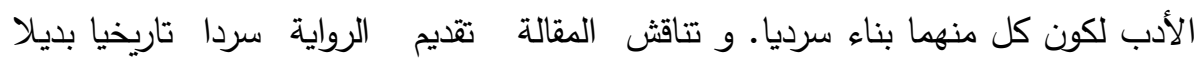

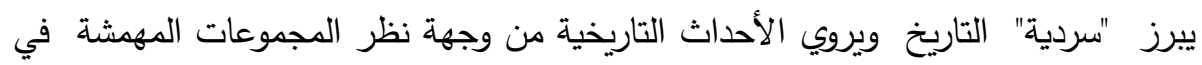

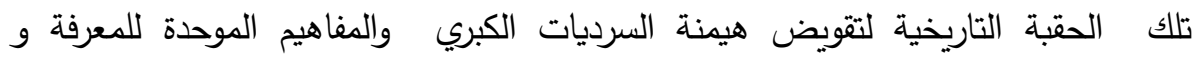
لإحداث تغيير في إنتاج المعرفة ليصبح أكثر شمولا و توازنا. وتعرض المقالة المبنة استخدام

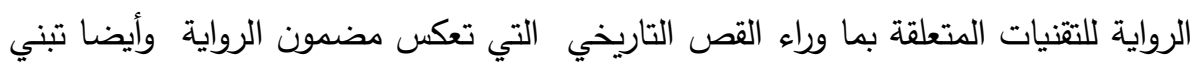

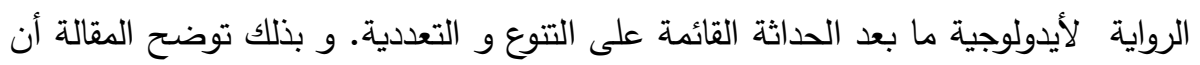

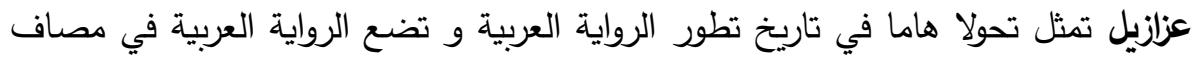

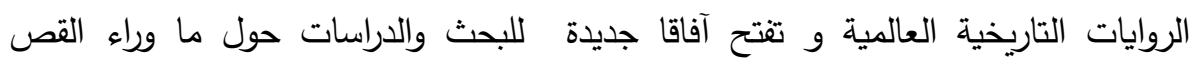
التاريخي. 


\section{Introduction}

Azazeel (2008) is the controversial second novel by Youssef Ziedan, the Egyptian writer, university professor, and scholar of Islamic philosophy and ancient manuscripts. It won the International Prize for Arabic Fiction (IPAF) in 2009, and it was translated into twenty five languages. It is well-known that the novel outraged a large number of Egyptian Orthodox Christians for what they considered the novel's hostile attitude towards their religious doctrine and leading figures in the early Church of Alexandria. This article maintains that the novel does not stop at its problematic religious content. Drawing on Linda Hutcheon's theory on historiographic metafiction, the article reads Azazeel as a representative example of Arabic historiographic metafiction. It calls attention not only to the novel's hitherto-disregarded epistemological import, pertaining to the nature and limits of narrative representations of historical knowledge and the politics of their production, but also to an important shift in the evolution of the Arabic historical novel by the development of what has so far been regarded as a predominantly Western genre, i.e. historiographic metafiction.

Although in the last few decades, numerous studies have been conducted on historiographic metafiction, none of them mentions any typical example from Arabic literature. The article argues that, together with a clear socio-political import, Azazeel has an additional epistemological import, articulated in the novel's historiographic metafictional narrative which, in accordance with Hutcheon's theory, provides an alternative history that foregrounds the 'narrativity' of historical narratives and represents the past from a 'marginal' perspective to question the absolute authority of metanarratives, undermine monolithic notions of knowledge, and develop a balanced production and dissemination of knowledge.

For a long time, history has been a major source of inspiration for 
novelists in the Arab world and, across different periods, they have adapted historical material in their novels for a variety of purposes. The article begins by sketching a brief outline of key moments in the history of the development of the Arabic historical novel. For, in order to really understand and appreciate the significance of Azazeel, as a historiographic metafiction, one must see it in relation to the tradition of the Arabic historical novel to which it belongs and wherein it represents a significant addition.

\section{An Overview of the Rise and Development of the Arabic Historical Novel}

Although, as Baian Rayhanova puts it, the definition of the genre "has become a vexed question" (71) in recent times, the historical novel remains a "child of mixed parentage" that "claims the right of invention reserved for fiction, but claims, also, to be based on historical reality" (Porter 315) . Whereas the historical novel appeared in Europe in the early nineteenth century when Sir Walter Scott's Waverly was anonymously published in 1814, the genre made its first appearance in the Arab world towards the end of the nineteenth century. As Mansour El-Hazmi puts it, "[i]n the last thirty years of the nineteenth century, a new literary genre was born in modern Arabic literature which was destined to live, to grow, and to attain, in due course, a certain maturity" (9).

Whether the Arabic historical novel has foreign or indigenous origins is a matter of continued controversy among scholars. Although the impact of traditional Arabic historical romances cannot be overlooked (El-Hazmi 20), it is widely acknowledged that the European historical novel played no small part in bringing about the rise of the Arabic historical novel. All previous studies that tackle the development of the Arabic historical novel stress the fundamental role of the Syro-Lebanese émigrés who came to Egypt after the 1860 massacre; they were in charge of a substantial number of journals which regularly devoted space to the publication of fiction, including 
translations of Western historical novels. According to Matti Moosa, despite the poor quality of the translations, their impact was immense (81). It was mainly through them that Arab writers in the nineteenth century could read, and afterwards emulate, European models such as Alexandre Dumas 's Le comte de Monte Cristo (1844) which gained enormous popularity at that time; and an interest in historical novels was created.

\section{The First Phase: The Educational Arabic Historical Novel}

The first historical emergence of the Arabic historical novel is always attributed to Salim al-Bustani, the Lebanese journalist, translator, and novelist who is rightly called "the precursor of the historical novel" (El-Hazmi 67). He published three historical novels: Zanubiya (Zanubiya, 1871), Budur (Budur, 1872), and Al-Hayam fi Futuh al-Sham ( Passion during the Conquests of Syria, 1874). However, it is Jurji Zaydan, the Lebanese historian, writer, and editor of the Egyptian periodical al-Hilal, who is often regarded as the real father of the Arabic historical novel (El-Hazmi 83-4). A few years after al-Bustani's attempts, Zaydan "embarked upon his prolific novel-writing career" (Moosa 157) and wrote twenty one historical novels which cover different periods of Arab-Islamic history, thus establishing the historical novel as a distinctive genre in Arabic literature. Notable among the works which appeared during the earliest phase are Farah Antun's Urshalim al-Jadidah (New Jerusalem, 1904); Ya'qub Sarruf 's Amir Lubnan (The Prince of Lebanon, 1907); and Ahmad Shawki's 'Adhra'a al-Hind aw Tamaddun al-Fara'inah ( The Virgin of India, or the Civilization of Pharaohs, 1897), Ladyas (Ladyas, 1899), and Dall wa Taiman, aw Akhir al-Fara 'inah (Dall and Taiman, or the Last of the Pharaos, 1899) (El-Hazmi 168). The first generation of Arab historical novelists also included women authors such as Zaynab Fawwaz who wrote Husn al-'awaqib aw Ghadat al-zahira (Fine Consequences, or Radiant Ghada) in 1899 and al-Malik Qurush (King Cyrus) in 1905 
(Elsadda 106-108) and Labiba Hashim who wrote Sherin in 1907 (Booth 146).

Those early historical novels offered their readers entertainment as well as education about the history of the Arab nation and other nations; they mixed historical material with elements of romance to meet the taste of the reading public at that time. Nevertheless, most of them abound with technical and thematic flaws. For example, alBustani's "plots are weak, his characters lack depth and individuality and his themes are superficial" (Moosa 6) and he "stuffed his historical novels with long reformatory essays and innumerable didactic comments" (El-Hazmi 58). Similarly, Zaydan was often criticized not only "for apparently being strongly influenced by Orientalists; for choosing points of conflict in Arab-Islamic history rather than its "glories" as the focus of his novels; for his faithfulness to historical record at the expense of plot and character development; and his reliance on narration and simplified dialogue that often makes use of colloquialisms" but also for generalizing those flaws due to his big influence on his contemporary writers (Hassan 31). Notwithstanding such imperfections, it would not be fair to deny the historical novelists of the first phase the merit of at least popularizing the nascent genre. They initiated the Arabic historical novel's long process of development which eventually evolved into the postmodern form of historiographic metafiction represented by Azazeel.

\section{The Second Phase: The Nationalist Arabic Historical Novel}

The years that followed the end of World War I represented an intermediate period that brought about the transition from the historical novels of al-Bustani, Zaydan, and their contemporaries to those of the 1940s, historically viewed as the second phase in the development of the Arabic historical novel. Political events such as the European colonization of Arab countries, the spread of anticolonial sentiments, and the rise of Arab nationalism were of crucial 
importance in this regard. In their struggle to free themselves from the yoke of foreign occupation, the Arabs felt the need to assert their independent identity by reviving their historical heritage. It was natural that the historical novel was a medium they resorted to, and writing about their national past increasingly became a major interest for Arab novelists until it turned into a vogue in the 1940s.

In Egypt, in the early post-war years, there were many calls to revive Pharaonic history and to draw inspiration from ancient Egyptian civilization. As Donald Malcolm Reid puts it, "[p]haraonism - popular interest in, and identification with, ancient Egypt - was a prominent strand in Egyptian territorial nationalism, the dominant ideology of the 1920s" (109). In this context, Muhammed Husain Haikal, the prominent Egyptian journalist and novelist, not only "devoted many pages of his newspaper al-Siyasa (and especially in its weekly supplement) to Pharaonic literature, art, and history" (Somekh 27) but also wrote four Pharaonic short stories (El-Hazmi 206). Yet, despite the grandeur of the Pharaonic civilization and its strong appeal for many Egyptian intellectuals of the 1920s, as Richard Hrair Dekmejian remarks, "anchoring modern nationalism on the pharaonic period had a ring of unreality, especially to Muslim Egyptians" (91-2). Accordingly, enthusiasm about the Pharaonic history gradually abated, and Egypt's affiliation to its Arabic and Islamic history eventually took precedence.

Then, the fourth decade of the twentieth century witnessed the "second flowering" (El-Hazmi 275) of the Arabic historical novel. It was a decade marked by a dramatic rise in the number of novels dealing with historical topics. They were set apart from their predecessors by not only formal improvements such as nondigressive narratives and coherent plots but also their dissemination of a collective memory based on either Pharaonic, Arab, or Islamic history. The Pharaonic trend was exemplified by novels such as Nagib Mahfouz's Abath al-Aqdar (Mockery of the Fates, 1939), 
Rhadopis (Rhadopis, 1943 ), and Kifah Tiba (The Struggle of Thebes, 1944); Adil Kamil's Malik min Shu'a ( A King of Sunbeams, 1945); and 'A'isha Abd al-Rahman's Raj'at Fir'awn (Pharaoh's Resurrection, 1948). Conspicuous among the literary works of the post-war years is Muhammed Farid Abu Hadid's historical novel Ibnat al-Mamluk (The Mameluke's Daughter, 1926). It not only heralds significant changes in both the thematic and technical aspects of the Arabic historical novel but also gives the earliest expression of the rising Arabic trend at that time (El-Hazmi 243-4). Then, in the 1940s, Abu Hadid, "the most competent representative of the Arabic trend" (Somekh 29) returned to the literary scene with several historical novels, all set in the pre-Islamic Arab world: Zinubya, Malikat Tadmur (Zinubya, Queen of Palmyra, 1941), alMuhalhil Sayyid Rabi'a (al-Muhalhil, Chief of Rabi'a, 1944) , al-Malik al Dilil (The Stray King, 1944), and Abu al-Fawaris Antara ibn Shaddad (The Greatest of Knights, Antara Ibn Shadad, 1946 ).

Ibrahim Ramzi's Bab al-Qamar (The Gate of the Moon, 1936) and Ma'ruf Arna'ut's Tariq ibn Ziyad (Tariq ibn Ziyad, 1941) may have been the earliest representative examples of the growing Islamic trend of the 1940s. However, it was later best exemplified by Ali Ahmad Bakathir's Salama al-Qass (Salama the Priest, 1943), Wa Islamah (O For Islam, 1945), and al-Tha'ir al-Ahmar (The Red Revolutionary, 1948); Abdel Hamid Gouda El Sahhar who wrote Saad ibn Abi Waqqas (Saad ibn Abi Waqqas, 1945) and Amirat Cordoba (The Princess of Cordoba, 1949); Mohammed Sa'id al'Aryan who wrote Qatr al-Nada (Drops of Dew, 1945), Shajarat alDurr ( Shajarat al-Durr, 1947), and Ala Bab Zuwayla (On the Zuwayla Gate, 1947); and Ali al-Jarim, the famous Egyptian poet, who "produced several accounts of the lives of the Arab poets al-Mu'tamid (d. 1091) (Sha'ir Malik), Abu Firas (d.967) (Faris Bani Hamdan), alMutanabbi (d. 965) (al-Sha'ir al-Tamuh and Khatimat al-Mataf), alWalid ibn Yazid (Marah al-Walid) and 'Umara al-Yamani (Sayyidat 
al-Qusur) in the mid- and late 1940s" (Gershoni and Jankowski 131). Despite their different choices from historical material, the historical novels of the second phase shared an unmistakable nationalist dimension; they represented glorious periods to encourage their readers to take pride in their nation and recover its former glories.

\section{The Third Phase: The Critical Arabic Historical Novel}

But the "golden age of the Arabic historical novel" ( El-Hazmi 274) was short-lived. In the 1950s and 1960s, when many Arab countries conducted successful revolutions and declared their independence, the quest for national identity ceased to be the primary concern for Arab novelists, and they "turned their backs on the past" (El-Hazmi 274). Instead, they focused their attention on the present, and the nationalist historical novel of the 1940s was replaced by the social realist novel which appeared to be a more appropriate genre for representing the new political and social conditions. Nevertheless, the defeat of the June war of 1967 followed a few years later by the devastating effects of Lebanon's civil war (1975-1990)- soon engendered bitter disillusionment and disappointment, prompting the development of a different kind of the Arabic historical novel. Roger Allen describes the situation in the wake of the 1967 war as follows:

And then came the June war of 1967, an event that, in the words of the Egyptian critic Farouk abd al-Qadir, involved "a defeat of regimes, foundations, structures, ideas, and leaders" (1979, 164). If the emphasis in the initial decades of the post-independence era (1950s and 1960s) on the portrayal of the present had tended to downplay the role and fictional use of history, then the period of intense selfquestioning and the search for alternative identities and values that followed the Naksa ("setback," as the June war was termed) certainly involved another, albeit different, examination of the past. (58)

During this period, a politicized generation of Arab historical 
novelists appeared in different Arab countries; they composed novels in which fictionalizations of historical eras were the means by which they commented critically on current political realities. It was in this context that Gamal al-Ghitani wrote al-Zayni Barakat (1974), "a work that was to signal a new phase in the Arabic historical novel" (Allen 58) and during the last quarter of the twentieth century, other Arabic historical novels in a similar vein appeared such as Abdul Rahman Munif's Mudun al-milh (Cities of Salt, 1984-1989), Bensalim Himmish's Majnun al-Hukm (Power Crazy (The Theocrat), 1989), and Radwa Ashour's Thulathiyyat Gharnata (Granada Trilogy, 19941995). They are marked by not only formal innovations such as fragmented non-chronological narratives and multiple points of view but also their distinct approach to history. Unlike the Arabic historical novels of the earlier phases, they neither patriotically boast about former glories nor picture idealized historical periods where military prowess, honour, and other heroic ideals prevail. Instead, they depict dark hells of arbitrary arrests and cruel tortures as in alZayni Barakat; of hypocrisy and illusory civilizations as in Mudun al-milh; of despotic rulers and dictatorships as in Majnun al-Hukm; and of cultural loss and dispossession as in Thulathiyyat Gharnata.

They have neither the educational function of Zaydan's novels nor the nationalist dimension of the novels of Mahfouz or Bakathir. They allegorically manipulate history to impart their critique of political conditions in the Arab world, and they often produce narratives largely at variance with those of recorded history. For example, as Susanne Enderwitz puts it, "[w]riting a historically informed story as an "antidote" to official historiography, as a tertium datur (third alternative) to the respective views of the West and the Arab rulers, is probably the strongest motive behind Cities of Salt" (142-3). With their critical stance towards official institutions and their ideologies, the novels of the third phase paved the way for what may well be called a decisive "postmodern turn" in the history of the 
development of the Arabic historical novel, represented by Azazeel.

\section{Azazeel as Historiographic Metafiction}

Concomitant with the recent surge in the popularity and sales of historical fiction worldwide (De Groot 1-2), novelists in the Arab world continue to evince considerable interest in the genre with the advent of the twenty-first century. Mohamed H. Tobail writes:

It is notable that the historical novel is becoming increasingly popular throughout the Arab world today. In Egypt, Youssef Zeidan wrote Azazil (Azazel (Azazeel), 2008), going back as far as the fifth century B.C. when Christianity became the official religion of the Roman empire. The novel depicts, on the one hand, the internal Christological conflict within the early Church and, on the other hand, the external conflict between the 'new' believers and the receding paganism. Wasini Al Araj from Algeria wrote Kitab al-Amir: Masalik Abwab al-Hadid (The Prince's Book: the Paths of the Iron Gates, 2005) ... Binsalim Himmish , a prominent Morrocan historical novelist, wrote Haza al-Andausi (This Andalusian (A Muslim Suicide), 2007) ... Ibrahim al- Kuni, the well-known Libyan novelist, wrote many novels in which history was employed for contemporary and cultural purposes such as Janub Gharb Tirwadah, Janub Sharq Qartajah (South-West of Troy, South-East of Carthage, 2011), Yusuf bila Ukhwatih (Yusuf without his Brothers, 2008), and Yaqub wa Ibnauh ( Yaqub and his Sons, 2007). (158-9, my translation)

The article maintains that Azazeel represents a significant departure from the novels of the previous phases, bringing about a discernible shift in theme, perspective, and technique, and marking the emergence of historiographic metafiction in the tradition of the Arabic historical novel. Typical of historiographic metafiction, the novel employs metafictional techniques to thematize narrative representation as a mode of knowledge in both fiction and historiography, emphasizing 'narrative', whether it be fictional or 
historical, as "a human-made structure - never as 'natural' or given" as well as "a mode of 'totalizing' representation" (Hutcheon 2002, 59). Like its immediate predecessors, Azazeel utilizes historical material to comment critically on the present, but, unlike them, its message is not limited to a critique of political conditions. Typically, its critical perspective expands to include conventional historiographical claims to objectivity; by employing the historiographic metafictional techniques of intertextual parody and paratexts , it provides meditations on the nature and limits of narrative representations of historical knowledge, contesting their impartiality and laying bare the fictional elements which are inevitably involved in their construction and the political factors which come into play in their production.

In Azazeel, the narrative's implications for the present are manifest. It clearly denounces the phenomenon of the so-called religious, or religiously-motivated, violence which is increasingly becoming a feature of political and social life in many parts of the world today. It traces its long history, shatters the myth of its being motivated solely by religion, and emphasizes its devastating consequences on individuals and communities at large. Ziedan continuously asserts that the past and the present are not disconnected and that our knowledge of history should inform the present. For instance, in Matahat Al-Wahm (Labyrinths of Illusions, 2013), he states that, "history is neither an intellectual luxury nor a form of abstract knowledge; history is the first step towards coming to terms with the present and effecting a thorough understanding of it" (18, my translation). Reflecting this notion of the past and the present as moving in a continuum, Azazeel employs the technique of circular structure and Hypa, the narrator-protagonist, inaugurates his narrative with the following words:

Where should I begin my narrative? The beginnings are interwined, teeming in my head. Perhaps, as my teacher Syrianus used to say, 
beginnings are merely delusions we believe in, for the beginning and the ending exist only along a straight line, and there are no straight lines except in our imagination or on the scraps of paper where we trace our delusions. In life and in all creation, however, everything is circular, returning to where it began, interwoven with whatever is connected. There is in reality no beginning and no ending, only an unbroken succession. ( 7)

Azazeel revolves around the Syriac-Arabic translation of a narrative account of the turbulent historical period of the fifth century A.D. in Egypt and northern Syria, dramatizing violent clashes between Christians and pagans in fifth-century Alexandria, the horrific murder of Hypatia, and the Christological conflict between Bishop Cyril of Alexandria and Bishop Nestorius of Constantinople that led to the latter's excommunication and exile. It is an eye-witness account by Hypa, the Egyptian physician-monk, who lived through personal and collective ordeals that led his faith to collapse, and therefore, at the narrative's outset, he cries out:

Why has everything gone dark? The light of faith which used to shine inside me, the peace of mind which kept me company in my loneliness, like a candle in the night, my serenity within the walls of this gentle room, even the daylight sun, I see them today extinguished and abandoned. (10)

The narrative begins in medies res, in Jerusalem, the city where the perplexed Hypa, has gone in an attempt to regain the certitude and balance he lost after shattering experiences in the city of Alexandria. Jerusalem offers Hypa the opportunity to meet two prominent historical personages, namely, Bishop Theodore of Mopsuestia and Nestorius, the Antiochian priest who, according to historical sources and the novel, was nominated by the Roman emperor Theodosius II to become Archbishop of Constantinople from 428 to 431 . Whereas traditional Arabic historical novels celebrate illustrious historical figures, Azazeel, -- as a typical historiographic 
metafiction - valorizes 'ex-centric' historical ones about whom condemnatory attitudes tend to prevail: "Historiographic metafiction espouses a postmodern ideology of plurality and recognition of difference; "type" has little function here, except as something to be ironically undercut" (Hutcheon1988 114). During their first conversation in Jerusalem, Nestorius unwittingly revives painful memories which Hypa has been trying to suppress. In an extended flashback, Hypa recalls tragic experiences he had earlier in his life not only in Naga Hammadi, his native village, but also in Alexandria to which he travelled many years before, inspired by the hope "to excel in medicine and theology" (73).

Unlike the historical novels of Zaydan in which the love interest is used merely to amuse and mitigate the monotony of recounting historical events (El-Hazmi 108), the theme is employed in Azazeel to set the plot in motion and underline major thematic concerns. Towards the end of the novel, Hypa goes through the passionate love affair with Martha, the choir singer, an experience which heightens his discontent and prompts him to break away his captivity in monastic life. But, earlier in the novel, Hypa meets Octavia, an Alexandrian pagan widow with whom he indulges in forbidden pleasures and becomes on the verge of giving up his "great dream" (73). The episode with Octavia not only points out the bond of humanity that transcends the barriers set up by religious differences but also provides one of the novel's several manifestations of the theme of religiously-motivated violence. In a memorable scene, Octavia speaks irreverently about Bishop Theophilus of Alexandria and his nephew, Bishop Cyril, whom she holds responsible for her husband's death during the destruction of a pagan temple by Christians; and Hypa becomes so irritated that he is forced to reveal his true identity which he has kept hidden. Then, like the huge sea waves that separated them when they first met on the Alexandrian sea shore, religious differences eventually erect unsurmountable barriers 
between them, and put an end to their illegitimate love.

However, it is the novel's depiction of the brutal murder of Hypatia, the world's first eminent female philosopher and mathematician, that represents the novel's most powerful expression of extremist violence. Hypatia, the real historical figure who was " the daughter of the scholar Theon, the Pythagorean professor," (88) is another pagan woman who accidentally comes into Hypa's way in Alexandria and brings about the dramatic transformation of his life. In the novel's climactic scene, Hypa describes how, led by "Peter the gospel reader at the Caesarion church" (123), a fanatic mob commit their heinous crime:

His hand grabbed at her and other hands grabbed too. It was as if she were floating on a cloud, held up on their hostile arms, and in broad daylight the horror began. The sea of hands attacked like weapons: some opened the carriage door, others pulled at the trail of her silk dress, others grabbed Hypatia by the arm and threw her on the ground. She had her long hair tied up like a crown on her head, but the hair fell loose. Peter dug his fingers into it and twisted the braids around his wrist. When she screamed, he said, 'In the name of the Lord, we will purge the land of the Lord. (125-6)

The image of Hypatia "when her skin had been peeled off her flesh and her organs shredded"(142) must bring to the minds of contemporary readers images of current atrocities such as those committed by the so-called 'jihadists' and other extremist 'religious' groups, also in the name of religion. Throughout this scene, the ironic reiteration of the refrain, "In the name of the Lord, we will purge the land of the Lord" highlights how extremists "manufacture legitimacy" (Awan 6-8) for their detestable crimes by misusing religious phrases and texts. Repeated references to the story of Jesus Christ when he saved the adulterous woman from the people who unmercifully stone her expose the false pretence of such extremists who claim to act in the name of religion. Throughout the 
novel, what is implied is that Azazeel, not God, is the motivating force behind all such atrocities; and hence, the novel is aptly named after that demon, whether he is "a metaphysical entity outside of us" or "the impediment within" (Mahmood 268). During one of their conversations in Jerusalem, Nestorius says to Hypa, "what's happening in Alexandria has nothing to do with religion"; he asserts, "[k]illing people in the name of religion does not make it religious" (151).

Aghast and stunned, Hypa watches the 'butchering' and burning of Hypatia. The incident arouses the painful childhood memory of witnessing his pagan father's murder in similar circumstances: A group of Christians "pulled my father from his boat and dragged him across the rocks to stab him to death with rusty knives" (28) for bringing fish to pagan priests besieged in their temple. More importantly, Hypatia's screams continue to throb in Hypa's head long after her remains vanished into burning smoke, and the incident powerfully shakes the very foundation of his faith. He flees from "the capital of salt and cruelty" (42) and never returns to it. In an attempt to alleviate his pain and start anew, he wades into the water of the vast marshes at the end of the Nile Delta, takes off all his clothes, recites a prayer, and baptizes himself, giving himself "a new name , the name I am still known by - Hypa - which is just the first half of her name" (134).

The novel's representation of the internal conflict within the early Church that led to the excommunication of Bishop Nestorius of Constantinople effectively combines with the earlier episodes to construct a narrative that powerfully condemns religious extremism in all its forms. Hypa's spiral narrative eventually takes the reader to the monastery near Aleppo where Hypa hopes to find inner tranquility. A little after his arrival, news of the Christological conflict that arises between Bishop Cyril and Bishop Nestorius start disturbing him and disrupting his peace of mind. As the news of the 
calling and the holding of the council of Ephesus in 431 and of "poor Nestorius, who will soon join those excommunicated before him" (285) reach the monastery, Hypa falls ill and his faith nearly collapses. Significantly, Azazeel becomes Hypa's constant companion at that time, obviously luxuriating in such an atmosphere of unrelenting contention and violence. Hypa remarks, "I was surprised that he was not hiding and that when he appeared he was not morose" (301). Many unanswered questions keep racing in Hypa's mind, aggravating his sickness: "What in the first place is the true faith, to which heresies might be the opposite? There could be no heresies if there were no orthodoxy. And what is orthodoxy? Is it what they decree in Alexandria, or what they believe in Antioch?" (285). As the conflict between the heads of the big churches soars, Hypa retires to his monk's cell where he begins and ends his narrative; and under Azazeel's influence, he begins to narrate the events he witnessed. As forty days of retirement come to an end, the narrative comes full circle and Hypa expresses his intention to depart from the monastery and give up monastic life, "free" (307) but still "lost in uncertainty and doubt" (Abu Baker 39).

This article argues that, in Azazeel, the socio-political message is combined with an equally important epistemological one. Typical of historiographic metafiction, it presents an alternative history of the events of the period in question not only to allow a narrative space for those who were silenced in the authorized historical records but also to emphasize the diversity of historical narratives and combat the totalizing impulse or the process "by which writers of history, fiction, or even theory render their materials coherent, continuous, unified - but always with an eye to the control and mastery of those materials, even at the risk of doing violence to them" (Hutcheon 2002, 59). Hence, violence in the political and social spheres as well as in the domain of historiography is a major theme in Azazeel.

In fiction, according to Hutcheon, postmodernism is typified by 
what she terms "historiographic metafiction", the postmodern variant of the historical novel, on which her views are elaborated in her two seminal works A Poetics of Postmodernism ( 1988 ) and A Politics of Postmodernism ( 2002) as well as in a number of influential articles: "The term, postmodernism, when used in fiction, should, by analogy, best be reserved to describe fiction that is at once metafictional and historical in its echoes of the texts and contexts of the past. In order to distinguish this paradoxical beast from traditional historical fiction, I would like to label it 'historiographic metafiction'" (Hutcheon1989, 3 ). For Hutcheon, historiographic metafiction exemplifies the critical attitude of postmodern culture towards traditional conceptions of both fiction and history. On the one hand, it challenges "any naive realist concept of representation and any equally naïve textualist or formalist assertion of the total separation of art from the world" $(1989,6)$; on the other hand, it foregrounds the postmodern epistemological questioning of the nature of historical knowledge, contesting the presumed objectivity of history narratives. Hutcheon further maintains that historiographic metafiction emphasizes narrative discourse as being "both an instrument and effect of power" (1988, 185). She states that "[h]istoriographic metafiction shows fiction to be historically conditioned and history to be discursively structured, and in the process manages to broaden the debate about the ideological implications of the Foucaldian conjunction of power and knowledge - for readers and for history itself as a discipline" (1988, 120). In addition, Hutcheon observes that historiographic metafiction enacts the views of certain contemporary historiographers and deals with issues that have been in the foreground in the field of historical studies, especially since the publication of Hayden White's Metahistory (1973). She writes:

Historiographic metafiction is written today in the context of a serious contemporary interrogating of the nature of representation in historiography. There has been much interest recently in narrative - 
its forms, its function, its powers, and its limitations - in many fields, but especially in history. Hayden White has even asserted that the postmodern is "informed by a programmatic, if ironic, commitment to the return to narrative as one of its enabling presuppositions" (White 1987: xi). If this is the case, his own work has done much to make it so. $(2002,47-8)$

Significantly, Azazeel presents a narrative that blurs the distinction between fiction and history, one which is at once a fictional autobiography, i.e. a novel, and a history. Typical of historiographic metafiction, Azazeel tacitly addresses the issue of 'narrativity'. It posits the notion of narrative representations, fictional and historical, as constructions -- not reflections - of past realities, highlighting processes of selecting, ordering, and constructing that are inexorably involved in them. Hypa's real name which remains a mystery throughout the novel stands for information which a historian may choose to withhold; and typically, throughout the novel, "[t]he narrativization of past events is not hidden; the events no longer seem to speak for themselves, but are shown to be consciously composed into a narrative, whose constructed - not found - order is imposed upon them, often overtly by the narrating figure. The process of making stories out of chronicles, of constructing plots out of sequences, is what postmodern fiction underlines" (Hutcheon 2002, 63). Hypa's narrative begins with a metafictional representation of the act of narration, picturing Hypa as he, in a trembling hand, starts to write as follows:

In the name of God on high, I hereby start to write my life as it has been and as it is, describing what happens around me and the terrors that burn within me. I begin my chronicle (and I do not know how or when it will end ) on the night of the 27th day of the month of Thout (September) in the year 147 of the Martyrs, that is the year 431 of the birth of Jesus the Messiah, the inauspicious year in which the Venerable Bishop Nestorius was excommunicated and deposed, and 
in which the foundations of the Faith were shaken. (7)

Similarly, the rest of the narrative self-consciously highlights its own narrativity, especially through its frequent use of the metafictional device of abrupt interruptions of flashbacks to return to the present while Hypa is engaged in the act of composing his narrative. Throughout the novel, there are scenes in which Hypa suddenly stops writing about the past and comes back to the present moment (36-7/ 77-8/ 125); and, in such scenes, the accursed Azazeel appears before him to urge him to resume writing about "the events of his troubled life and the vicissitudes of the turbulent age in which he lived" (1). For example, as he begins recounting the horrific tale of how Hypatia was unmercifully tortured to death, the narrative abruptly stops and Hypa writes:

I won't write another word, no.

Lord, still my hand. Take me unto you. Have mercy on me.

I'll tear up the parchments. I'll wash them in water, I'll ...

"Write, Hypa, write in the name of the truth, the truth preserved in you."

“Azazeel, I can't"

"Write and don't be a coward, for what you have seen with your eyes, no one but you will write down, and if you conceal it no one will know of it."

"I told Nestorius about it, in Jerusalem years ago."

"Hypa, that day you told a part of it. Today write it down in full, write it all now." (125)

Constant interruptions and returns stress the constructed nature of Hypa's narrative as well as other narrative representations of historical knowledge; they point out that, both history and fiction are "discourses, human constructs, signifying systems" and that "both genres unavoidably construct as they textualize that past. The "real" 
referent of their language once existed; but it is only accessible to us today in textualized form: documents, eye-witness accounts, archives" (Hutcheon 1988, 93).

Historiographic metafiction, according to Hutcheon, points out that history-writing, like fiction-writing, is subjective and perspectival and that "[f]acts do not speak for themselves in either form of narrative: the tellers speak for them, making these fragments of the past into a discursive whole" $(2002,56)$. Throughout Azazeel, what is implied is that a historical narrative, like a fictional one, is a selective perspective on the past rather than a replica or an exact imitation of it; it is inevitably tied up with the narrator-historian's viewpoint and the ideological commitments and interests of the particular group who produce it. In the novel, Hypa, whose point of view dominates the narrative, is depicted as an ardent supporter of Nestorius. Their long conversations in Jerusalem develop a strong intimacy between them. For Hypa, Nestorius is not only "a priest with spiritual power, and a monk who deserved reverence" but also a father figure. Hypa writes: "I saw in him my father who was snatched from me, my lost father, although Nestorius did not resemble him in appearance and was not old enough to be the father of someone my age, other than in the ecclesiastical sense of the word" (41). Likewise, Hypa's personal experiences make him a fervent admirer of Hypatia. Unlike the fanatics who view Hypatia as "the last symbol of a dying paganism" (130) and jubilantly celebrate her murder, Hypa regards her as "the Savante of the Age, the pure and holy, the lady who suffered the torments of martyrdom and in her agony transcended all agonies" (127). Told from Hypa's perspective, it is not surprising that the narrative defends Nestorius's theological doctrine and supports the claim about Cyril's involvement in instigating the Christian mob against Hypatia. What is implied is that an objective narrative representation of the past is virtually inconceivable, however hard a historian may strive to achieve objectivity. 
Unlike the traditional Arabic historical novels which revive rather than contest official history narratives, Azazeel presents a counter narrative of the historical period in question. Although Ziedan does not make use "of the very freedom historical novelists have claimed for themselves ever since Sir Walter Scott's apologies for the genre" (Wesseling 159) and meticulously complies with the historical sources (Wright 311), the novel provides an alternative history that recounts the events of the period from the perspective of the silenced religious minorities at that time, namely, the worshippers of the old pagan deities and the supporters of Nestorius. In historiographic metafiction, according to Hutcheon, "[m]argins and edges gain new value. The "ex-centric" - as both off-center and de-centered-gets attention" (1988, 130). Unlike the metanarrative of the period in question, the narrative in Azazeel operates in the interests of the period's "marginalized ex-centrics" (Hutcheon1988, 200) to whom Hypa obviously belongs. Typical of the protagonists of historiographic metafiction, Hypa is one of "the ex-centrics, the marginalized, the peripheral figures of fictional history" (Hutcheon1988, 114). His marginal position is implied by his room in the Church of Resurrection which is situated on a border region, i.e. the edge, and Hypa believes "[t]he place suggested was right, halfway between the city and the church, neither here nor there, like me, betwixt and between" (14).

As Jerome de Groot puts it, "[h]istory in postmodernism is a grand narrative in need of undermining" (110). Exemplifying the postmodernist "incredulity toward metanarratives" (Lyotard xxiv), the novel brings to light a non-totalizing mini-narrative, i.e. one of the "smaller and multiple narratives which seek no universalizing stabilization or legitimation" (Hutcheon 2002, 24) to question the authority of the metanarrative of the period in question and shatter the myth of history narratives as objective representations of past events. It is noteworthy that the "metanarrative" alluded to in this 
article refers to a whole body of dominant narratives, based on ecclesiastical sources and subscribed to by the majority of Christians all over the world, rather than a single narrative. Wright remarks that "[m]ost of the extant histories of the period were in the hagiographic tradition, written by Copts for Copts to celebrate the sufferings and achievements of their martyrs and founding fathers" (309). Unlike the historical metanarrative which represents the period in question as a great era of victory that witnessed the rapid decline of paganism and the proclamation of Christianity as the official religion of the Roman empire, the mini-narrative in Azazeel represents it as a tragic era of extremist violence and continuing bloodshed.

Historiographic metafiction, according to Hutcheon, "does not "aspire to tell the truth" (Foley 1986a, 26) as much as to question whose truth gets told" (1988, 123). In accordance with Hutcheon's views, the historiographic metafictional narrative in Azazeel typifies White's statement "that history is written by the victors and to their advantage" (2008, 9), promoting the idea that the production of historical narratives is a political act. It explicitly makes the point that undeclared political factors played a crucial role in deciding the outcomes of both the First Council of Nicea in 325 and the Council of Ephesus in 431; they came into play not only in determining which of the two conflicting parties was victorious but also in legitimating the victors' s beliefs and privileging their narrative of the historical period. Explaining to Hypa what happened at the time of the First Council of Nicea in 325 when Arius, the priest, was excommunicated and deposed, Nestorius says that Emperor Constantine I "took sides with Bishop Alexander to secure Egypt's wheat and the annual grape harvest. He excommunicated Arius, banned his teachings and declared him a heretic to please the majority and make himself the champion of Christianity" (38). Similarly, informing Hypa about the proceedings of the Council of Ephesus in 431, Pharisee, his fellow-monk, says:

The bishops abandoned Nestorius, except for Bishop John of Antioch, and for well-known reasons the emperor and the pope of Rome did not 
want to anger Alexandria. When Bishop Rabbula and his people saw that the balance was in favour of Cyril they turned on Nestorius and denounced him. Then the council drafted a new creed, with additions to the creed endorsed a hundred years ago in Nicea. (299)

Accordingly, the production of the mini-narrative in Azazeel reveals that history-writing is not only, as White puts it, "an ideological weapon with which to double the oppression of already vanquished groups by depriving them of their historical pasts and consequently of their identities as well" $(2008$, 9) but also a weapon with which to fight that oppression and inscribe the losers into history.

According to Hutcheon, historiographic metafiction is, in more than one sense, a doubled and contradictory narrative. It is at once literary and historical; fictional and factual; imagined and real; and it is a narrative in which "the conventions of both fiction and historiography are simultaneously used and abused, installed and subverted, asserted and denied" (1989, 5). For Hutcheon, historiographic metafiction, like other postmodern art forms, provides through its use of the technique of intertextual parody what she calls "the paradox of postmodern complicitous critique" (2002 9); for "parody always implicitly reinforces even as it ironically debunks." She writes:

The language of margins and borders marks a position of paradox: both inside and outside. Given this position, it is not surprising that the form that heterogeneity and difference often take in postmodern art is that of parody - the intertextual mode that is paradoxically an authorized transgression, for its ironic difference is set at the very heart of similarity. $(1988,66)$

In Azazeel, the historiographic metafictional narrative conducts a typical complicitious critique. Admittedly, it sends out clear echoes of a variety of historical and literary intertexts such as Edward Gibbon's The History of the Decline and Fall of the Roman Empire (1776-1789), other historical narratives by "Protestants and 
Enlightenment scholars who used Hypatia' s murder to launch a broader critique of clerical excess and religious violence" (Mahmood 271), Charles Kingsley's Hypatia, or New Foes with an Old Face (1853), and Dan Brown's Da Vinci Code (2003). Paradoxically, however, one of the central intertexts of the counter narrative in Azazeel is the very metanarrative it contests. Although it challenges the metanarrative's claims to objectivity and its monopoly of historical knowledge, it inscribes it by parodying its matter and methods. "To parody," according to Hutcheon, "is not to destroy the past; in fact to parody is both to enshrine the past and to question it. And this, once again, is the postmodern paradox" (1988, 126). What is implied by the 'complicitous critique' in Azazeel is that the two conflicting narratives are inevitably embedded in each other as well as in the intricate network of historical, current, and even future texts - or intertexts - 'narratively' representing the events of the same historical period, whether in fiction or in historiography. Therefore, typically, the historiographic metafictional narrative in Azazeel embraces a postmodern ideology of heterogeneity, diversity, and pluralism, demanding a kind of historiography that acknowledges meta- as well as mini- narratives; for it is their interaction that constitutes historical knowledge in its totality. Hutcheon writes:

Historiographic metafictions are not "ideological novels" in Susan Sulieman's sense of the word: they do not "seek, through the vehicle of fiction, to persuade their readers of the 'correctness' of a particular way of interpreting the world" $(1983,1)$. Instead they make their readers question their own (and by implication others') interpretations. They are more "romans à hypothèse" than "romans à these. (1988, 180)

In Azazeel -- as in other historiographic metafictions - "we now get histories (in the plural) of the losers as well as the winners" (Hutcheon 2002, 63). Hence, the epistemological import of the historiographic metafictional narrative in Azazeel resides not only in 
its skeptical attitude towards the metanarrative or in its de-totalizing impulse but also in its affirmation of the need to rethink of historical knowledge production as a "space of "hybridity" rather than hegemony, of negotiation rather than negation, and of democratic inclusion rather than exclusion" (Ben Hania 2). It posits a notion of historical knowledge as too complex, varied, and dynamic to be encompassed in a single monolithic narrative, upholding the view that there are as many "truths" about the past as there are individual perspectives on it (White 1973, 332).

Sally Gomaa rightly remarks that, even after it won the prestigious international prize, "Azazeel did not receive the scholarly attention it deserved for its innovative narrative structure and literary technique" (957). The non-linear form of the narrative in Azazeel accentuates its contestatory attitude towards the historical metanarrative, enacting White's view on narrative as a multilayered discourse whose content consists as much of its form as of the historical information imparted through it (1987, 42). Typical of historiographic metafiction, a set of paratexts are further employed to establish the narrative's linkage to the present and assert its 'counter' stance. Dated 2004 and located in contemporary Alexandria, the "Translator's Introduction" not only embeds the historical narrative in the present temporal-spatial context but also aptly sets the framework for a narrative that contests the notion of a single narrative 'original' of historical knowledge; it poses 'translation' as a perfect trope for narrative representations whether in fiction or historiography: "Narrative is what translates knowing into telling $(\mathrm{H}$. White 1980, 5), and it is precisely this translation that obsesses postmodern fiction" (Hutcheon 1988, 121). The paratextual footnotes, inserted in the margins, is another strategy through which the counter narrative in Azazeel contests the veracity of the master narrative and combats its hegemony. On the one hand, they parody one of the long-standing conventions of history-writing, but, on the other hand, the disruptive footnotes remind the readers of the 
constructedness of the main text and refer them "to other texts, other representations first, and to the external world only directly through them" (Hutcheon 2002, 81). Hutcheon writes:

In historiographic metafiction these footnoting conventions are both inscribed and parodically inverted. They do indeed function here as self-reflexive signals to assure the reader as to the historical credibility of the particular witness or authority cited, while at the same time they also disrupt our reading - that is, our creating - of a coherent, totalizing fictive narrative, In other words, these notes operate centrifugally as well as centripetally. $(2002,81)$

The paratextual photographs in the Arabic text, which are notably missing in Wright's English translation, parody another one of the conventional outward features of historical narratives, and they foreground the artifice - the constructed nature - of visual as well as verbal narrative representations of the past. As Hutcheon puts it, "[1]ike writing, photography is as much transformation as recording; representation is always alteration, be it in language or in images, and it always has its politics" $(2002,8)$. Situated on the threshold, the novel's epigraph reads: "Every man has his devil, even me, but God helped me against him and he turned Muslim. A saying of the Prophet Muhammed cited by Bukhari" (Epigraph page). It directs the readers's attention to the specific context of Islam, i.e. to the changed religious context of contemporary Alexandria. It implicitly fosters an awareness of plurality and endorses tolerance and respect for difference as the only means to live peacefully and stop the ongoing cycle of extremism and violence .

Typically, the ending of the historiographic metafictional narrative in Azazeel defies "notions of closure, totalization, and universality that are part of those challenged grand narratives" (Hutcheon 2002, 67) implying that history is a narrative that can infinitely be re-appropriated, reconstructed, and rewritten. Hypa writes the following on the last parchment scroll:

Now the forty days have passed and my writing ends today. I have 
recorded only what I have remembered or experienced deep inside myself. This is the last piece of parchment and most of it is still free of writing. I shall leave that space blank in case someone comes after me to fill it. I will sleep a little now, then wake up before dawn, put the pieces of parchment in this box and cover it with soil under the big rock at the monastery gate. With it I will bury the fear I inherited and my old delusions. Then I will depart, as the sun rises, free ... (307)

With these words, and the ellipses at the end of the last sentence, the narrative comes to an end, not to a close. Although Azazeel is a tragedy of a reverse pilgrim's progress that counters the archetypal blissful progression from doubt and loss to faith and certitude, its ending envisages the possibility of a better future; 'sunrise' brings illumination, hope, and the chance of a new beginning.

\section{Conclusion}

Throughout the history of its development, the Arabic historical novel has always been a product of its time, and the article makes evident that Azazeel is no exception. Although the novel shares a number of fundamental features with its predecessors, it also differs significantly from them, bearing distinctive traits of postmodern historiographic metafiction such as intense selfreflexivity, juxtaposition of conflicting narratives, parodic playing with literary and historiographical conventions, intense intertextuality, and an additional epistemological import, providing illuminating insights into history as an object of knowledge in the present. "Contemporary Arab literature," writes Andreas Pflitsch, "needs to be taken seriously, dragged out of the exotic corner, and viewed on a par with contemporary world literature" (37). Without denying its heritage, Azazeel engages with the global postmodern condition, locates the Arabic historical novel within the wider context of world historical fiction, and opens up new avenues for research on historiographic metafiction. 


\section{Works Cited}

Abu Baker, Ahmed M.S. "The Problematics of Identity and Identity Erasure in Youssef Ziedan's Azazeel ." Journal of Arts\& Humanities. http://www.the artsjournal.org/index.php/ site/index

Allen, Roger. "The Arabic Novel and History." The Oxford Handbook of Arab Novelistic Traditions. Ed. Wäil S. Hassan. New York, NY : Oxford University Press, 2017. 49 - 65.

Awan, Akil N. "Success of the Meta-Narrative: How Jihadists Maintain Legitimacy." CTC Sentinel. November 2009. Vol. 2, 11, 6-8. http://ctc.usma.edu

Ben Hania, Rabeb. "The Historiographic Metafictional Writing of Power and the Power of Writing: historiographic metafiction in Thomas Pynchon's The Crying of Lot 49." American University Washington D. C. : Conference Paper, Apr 2014. http://www.academia.edu/10271346

Booth, Marilyn. "Women and the Emergence of the Arabic Novel." The Oxford Handbook of Arab Novelistic Traditions. Ed. Wäil S. Hassan. New York, NY : Oxford University Press, 2017. 135153.

De Groot, Jerome. The Historical Novel. Florence : Taylor and Francis, 2009.

Dekmejian, Richard Hrair. Egypt under Nasir : A Study in Political Dynamics , (Part 43). State University of New York Press, 1971.

El-Hazmi, Mansour I. The Modern Arabic Historical Novel. Thesis (Ph.D.) School of Oriental and African Studies (University of London), 1966.

Elsadda, Hoda. "Egypt." Arab Women Writers: A Critical Reference Guide, 1873-1999. Radwa Ashour et al. Cairo ; New York : American University in Cairo Press, 2008, 98 -161.

Enderwitz, Susanne. "Memories of the Future: Abdelrahman Munif". 
Arabic literature : Postmodern Perspectives. Edited by Angelika Neuwirth, Andreas Pflitsch, Barbara Winckler. London : Saqi, 2010, 134 -145

Gershoni, Israel and James P. Jankowski. Redefining the Egyptian

Nation, 1930-1945. Cambridge ; New York : Cambridge University Press, 1995.

Gibbon, Edward. The History of the Decline and Fall of the Roman Empire. Volume IV. New York : E.P. Dutton \& Co., 1910.

Gomaa, Sally. "The Uses of Geography in Youssef Ziedan's Azazeel" Arab Studies Quarterly Vol. 39, No. 4 (Fall 2017), 957-972.

Hassan, Wail S. "Toward a Theory of the Arabic Novel." The Oxford Handbook of Arab Novelistic Traditions. Ed. Wäil S. Hassan. New York, NY : Oxford University Press, 2017. 19-47. Hutheon, Linda. A Poetics of Postmodernism: History, Theory,

Fiction. London and New York Routledge, 1988.

A Theory of Parody: The Teachings of Twentieth

Century Art Forms. Urbana and Chicago : U of Illinois P, 2000.

---------- . The Politics of Postmodernism. London and New

York Routledge, 2002.

"Historiographic Metafiction: Parody and the

Intertextuality of History". Intertextuality and Contemporary American Fiction. Ed. O'Donnell, P., and Robert Con Davis.

Baltimore: Johns Hopkins University Press, 1989, 3-32.

Kingsley, Charles. Hypatia, or, New foes with an old face. New York: Frederick A. Stokes Company, 1890.

Lyotard, Jean-François. The Postmodern Condition: A Report on Knowledge. Minneapolis: University of Minneapolis Press, 1993.

Mahmood, Saba. "Azazeel and the Politics of Historical Fiction in Egypt." Comparative Literature. Summer 2013, Vol. 65 Issue 3, 265-284.

Moosa, Matti. The Origins of Modern Arabic Fiction. Washington, 
D.C. : Three Continents Press, 1983.

Pflitsch, Andreas. "The End of Illusions: On Arab Postmodernism". Arabic literature : Postmodern Perspectives. Edited by Angelika Neuwirth, Andreas Pflitsch, Barbara Winckler. London : Saqi, 2010. 25 -39

Porter, Dale H. "THE GOLD IN FORT KNOX: Historical Fiction in The Context of Historiography". Soundings: An Interdisciplinary Journal, Vol. 76, No. 2/3, (Summer/Fall 1993), 315-350.

Rayhanova, Baian. "The Past and the Present in the Modern Arabic Novel." Zeitschrift der Deutschen Morgenländischen Gesellschaft, Vol. 154, No. 1 (2004), 71-84. http://www.jstor.org/stable/43381577

Reid, Donald Malcolm. Contesting Antiquity in Egypt: Archaeologies, Museums, and the Struggle for Identities from World War I to Nasser. Cairo : American University in Cairo Press, 2015.

Somekh, Sasson. The Changing Rhythm: A Study of Najīb Mahfūz's Novels. Leiden, Brill, 1973.

Tobail, Mohamed H. The Historical Novel Changes in Arabic Literature. Thesis (M. A.) The Islamic University - Gaza, 2016.

Wagenaar, Hendrik. "Review." Administrative Theory \& Praxis. Vol. 23, No. 1. (Mar., 2001), 109-115.

Wesseling, Elisabeth. Writing History as a Prophet: Postmodernist Innovations of the Historical Novel. Amsterdam ; Philadelphia : J. Benjamins Pub. Co., 1991.

White, Hayden. Metahistory: The historical Imagination in Nineteenth-Century Europe. Baltimore : Johns Hopkins University Press, 1973.

Feminist Cultural Studies. Volume 19, Number 2, 2008, 9- 34. 
------------ . The Content of Form : Narrative Discourse and Historical Representation. Baltimore ; London : Johns Hopkins University Press, 1987.

Wright, Jonathan. "A Note on the Text." Azazeel . Trans. Johnathan Wright. London: Atlantic Books, 2012.

Zeidan, Youssef . Azazeel . Trans. Johnathan Wright. London: Atlantic Books, 2012.

. Matahat Al-Wahm. Cairo: Dar El-Shrouk, 2013. 